Int. J. Dev. Biol. 59: 171-177 (2015)

doi: $10.1387 / \mathrm{ijdb} .150071 \mathrm{tz}$

\title{
Histone deacetylases 1 and 2 are required for brain development
}

\author{
JOANNA JAWORSKA, MALGORZATA ZIEMKA-NALECZ and TERESA ZALEWSKA* \\ NeuroRepair Department, Mossakowski Medical Research Centre, Polish Academy of Sciences, Warsaw, Poland
}

\begin{abstract}
Epigenetic modifications of histones have been implicated in the regulation of cell specific expression of genes required for neuronal development. The best studied post-translational (epigenetic) modification of histones is the process of reversible acetylation. Two types of enzymes histone acetyltransferases (HATs) and histone deacetylases (HDACs) establish and maintain specific patterns of histone acetylation in balance, thereby contributing to both transcriptional activation and repression of specific sets of genes. Histone deacetylases catalyze the removal of acetyl groups from selected lysine residues in the conserved tails of core histone proteins and are considered as transcriptional corepressors. A significant amount of data implicates HDACs in diverse biological processes, including tissue specific developmental program by silencing specific growth-inhibitory genes. In line with this, gene disruption studies have shown that the class I deacetylases, HDAC1 and HDAC2 play an essential role in nervous system development. In the present review, we briefly highlight current insights supporting the function of histone deacetylases in rodent brain development and discuss present knowledge referring to their role in neurogenesis, taking into consideration results obtained in culture systems and in in vivo studies.
\end{abstract}

KEY WORDS: histone, deacetylase, brain, development

\section{Introduction}

Epigenetic modifications of both DNA and histones are emerging as essential mechanisms regulating many important cellular processes including the expression of genes required for neuronal development. One type of modification is a coordinated process carried out by two classes of nuclear enzymes, histone acetylases (HATs) and deacetylases (HDACs). Histone acetylation is a particularly important modification of histone amino-termini, because increased levels of histone acetylation are associated with transcriptionally-permissive chromatin, whereas deacetylation (hypoacetylation) with gene silencing (Strahl and Allis 2000; Marks et al., 2003; Saha and Pahan 2006). Thus, HATs and HDACs provide the enzymatic basis for transcriptional activation and repression, respectively, through alteration of the chromatin landscape. In addition, HDACs control gene expression by regulating acetylation of DNA sequence-specific transcription factors (Wilson et al., 2006).

A substantial body of evidence has documented the necessity of HDACs function for normal developmental processes by silencing the expression of specific growth-inhibitory genes (Lagger et al., 2002). The biological functions of individual HDACs have been difficult to determine due to the lack of isoform-specific pharmacological inhibitor agents. Nevertheless, the use of constitutive knockout (germline mutations) of many of the individual HDACs occurred to be lethal, either during embryonic or very early postnatal development with deleterious effects on distinct tissues or cellular processes recognized as the proximal cause of death (Lagger et al., 2002; Haberland et al., 2009a,b). Recent advances in this field have identified key roles for class I and class II HDACs in the proper development of specific tissues. Moreover, emerging literature now positions class I HDACS, HDAC1 and HDAC2 in particular, as important control points in brain development. The highly homologous HDAC1 and HDAC2 are detected at different stages of neuronal commitment and differentiation during central nervous system age-dependent evolution. This implicates their contribution to the regulation of the developmentally specific gene expression and to the maintenance of the CNS. These processes appear to be particularly sensitive to disruption in epigenetic gene

Abbreviations used in this paper: HDACs, histone deacetylases; HATs, histone acetyltransferases; CNS, central nervous system; ECM, extracellular matrix; VPA, valproic acid; NaB, sodium butyrate; TSA, trichostatin A.

\footnotetext{
*Address correspondence to: Teresa Zalewska. NeuroRepair Department, Mossakowski Medical Research Centre, Polish Academy of Sciences, 5 Pawinskiego Street, 02-106 Warsaw, Poland. Tel: 48-22 608-65-32. Fax: 48-22 608-66-23. E-mail: terezal@imdik.pan.pl
}

Accepted: 30 April 2015.

ISSN: Online 1696-3547, Print 0214-6282 
regulation, leading among others to syndromes associated with mental retardation (Egger et al., 2004) as well as complex psychiatric disorders (Grayson et al., 2005).

The primary objective of this review is to provide a brief overview of HDAC1 and HDAC2 function in neural development and summarize the current knowledge about their involvement in neurogenesis.

\section{Overview of the HDAC family}

Histone deacetylases (HDACs) are conserved enzymes that are found in organisms from Saccharomyces cerevisiae to humans. HDACs exist in multiprotein complexes with transcription factors, DNA-binding proteins and other chromatin modifying enzymes and their assembly into complexes is required for full deacetylase activity
(Zhang et al., 1999). HDACs regulate activity of their substrates by removing acetyl groups from lysine residues.

Molecular studies have shown that histone deacetylases are involved in epigenetic modifications that shift the balance toward chromatin condensation and silencing of gene expression and protein functions. In mammals, so far 18 deacetylases have been identified (Verdin et al., 2003). They are grouped into four different classes, based on DNA sequence similarity and function (Thiagalingam et al., 2003). Class I HDACs (HDAC 1, HDAC2, HDAC3 and HDAC8) display an extensive presence in nuclei and show ubiquitous expression in various mammalian cell lines and tissues. Class I HDACs have been most widely studied in their classical role as histone modifiers and transcriptional repressors. Class II HDACs further organized into class Ila (HDAC4, 5, 7 and 9) and IIb

\section{TABLE 1}

\section{CLASSIFICATION AND PHENOTYPES OF WHOLE BODY AND BRAIN-SPECIFIC KNOCKOUTS (KO) OF HISTONE DEACETYLASE (HDAC) ISOFORMS}

\begin{tabular}{|c|c|c|c|c|c|}
\hline & Co-factor & $\begin{array}{l}\text { Subcellular } \\
\text { localization }\end{array}$ & Constitutive KO defects & Conditional brain $\mathrm{KO}$ changes & References \\
\hline Class I & $\mathrm{Zn}^{2+}$ & & & & \\
\hline HDAC 1 & & Nucleus & $\begin{array}{l}\text { Lethal (E10.5); Severe proliferation defects and } \\
\text { general growth retardation }\end{array}$ & NR & $\begin{array}{l}\text { Lagger et al. 2002; Kim et al. 2008; Bardai et al. } \\
\text { 2012; Kim and Bae } 2011\end{array}$ \\
\hline HDAC 2 & & Nucleus & Die within $24 \mathrm{~h}$ after birth; Severe cardiac defects & Enhanced memory, LTP & $\begin{array}{l}\text { Montgomery et al. 2007; Guan et al. 2009; Kim } \\
\text { and Bae 2011; Morris et al. } 2013\end{array}$ \\
\hline HDAC 3 & & $\begin{array}{l}\text { Nucleus/ } \\
\text { Cytoplasm }\end{array}$ & Lethal (before E9.5) owing to defects in gastrulation & Enhanced episodic memory & $\begin{array}{l}\text { Montgomery et al. 2008; Bardai and D'Mello 2011; } \\
\text { Bardai et al. 2012; McQuown et al. 2011; Kim and } \\
\text { Bae } 2011\end{array}$ \\
\hline HDAC 8 & & Nucleus & $\begin{array}{l}\text { Deficiency of cranial neural crest cells, perinatal death } \\
\text { due to skull instability }\end{array}$ & NR & Haberland et al. 2009a,b \\
\hline Class Ila & $\mathrm{Zn}^{2+}$ & & & & \\
\hline HDAC 4 & & $\begin{array}{l}\text { Nucleus/ } \\
\text { Cytoplasm }\end{array}$ & $\begin{array}{l}\text { Lethal within } 7 \text { days owing to ectopic ossification of } \\
\text { endochondral cartilage, which prevents expansion of } \\
\text { the rib cage and leads to an inability to breathe }\end{array}$ & Impaired learning, LTP & $\begin{array}{l}\text { Vega et al. 2004; Kim et al. 2012; Sando et al. } \\
\text { 2012; Majdzadeh et al. 2008; Chen and Cepko } \\
\text { 2009; Kim and Bae 2011 }\end{array}$ \\
\hline HDAC 5 & & $\begin{array}{l}\text { Nucleus/ } \\
\text { Cytoplasm }\end{array}$ & Viable; Cardiac defects & $\begin{array}{l}\text { Enhanced cocaine sensitivity; } \\
\text { anhedonia; learning and memory } \\
\text { impairment }\end{array}$ & $\begin{array}{l}\text { Haberland et al. 2009a,b; Renthal et al. 2007; } \\
\text { Linseman et al. 2003; Agis-Balboa et al. 2013; Kim } \\
\text { and Bae } 2011\end{array}$ \\
\hline HDAC 7 & & $\begin{array}{l}\text { Nucleus/ } \\
\text { Cytoplasm }\end{array}$ & $\begin{array}{l}\text { Embryonic lethality owing to a loss of integrity of } \\
\text { endothelial-cell interactions and consequent rupture of } \\
\text { blood vessels and haemorrhaging }\end{array}$ & NR & $\begin{array}{l}\text { Chang et al. 2006; Ma and D'Mello 2011; Kim and } \\
\text { Bae } 2011\end{array}$ \\
\hline HDAC 9 & & $\begin{array}{l}\text { Nucleus/ } \\
\text { Cytoplasm }\end{array}$ & Viable; Cardiac defects & NR & $\begin{array}{l}\text { Haberland et al. 2009a,b; Morrison et al. 2006; Kim } \\
\text { and Bae } 2011\end{array}$ \\
\hline Class IIb & $\mathrm{Zn}^{2+}$ & & & & \\
\hline HDAC 6 & & Cytoplasm & Viable; increased tubulin acetylation & Hyperactive, anxiolytic & $\begin{array}{l}\text { Hubbert et al. 2002; Fukada et al. 2012; Pandey et } \\
\text { al. 2007a,b; Dompierre et al. 2007; Rivieccio et al. } \\
2009\end{array}$ \\
\hline HDAC 10 & & Cytoplasm & NR & NR & Kao et al. 2002 \\
\hline Class III sirtuins & $\mathrm{NAD}^{+}$ & & & & \\
\hline Sir 1 & & Nucleus & $\begin{array}{l}\text { Most mice die perinatally; retinal, bone and cardiac } \\
\text { defects }\end{array}$ & $\begin{array}{l}\text { Memory deficit, no adaptive feeding } \\
\text { response to Calorie restriction, less } \\
\text { serum IGF1 }\end{array}$ & Nakagawa and Guarente 2011; Finkel et al. 2009 \\
\hline Sir 2 & & $\begin{array}{l}\text { Nucleus/ } \\
\text { Cytoplasm }\end{array}$ & Viable & NR & Nakagawa and Guarente 2011 \\
\hline Sir 3 & & Mitochondria & $\begin{array}{l}\text { Defects in fatty acid oxidation, cancer prone, oocytes } \\
\text { exhibit developmental arrest after IVF, accumulation of } \\
\text { hyperacetylated mitochondrial proteins, reduced } \\
\text { respiration and ATP levels }\end{array}$ & NR & Nakagawa and Guarente 2011 \\
\hline Sir 4 & & Mitochondria & Appear healthy, increased mitochondrial GDH activity & NR & Finkel et al. 2009 \\
\hline Sir 5 & & Mitochondria & Defect in urea cycle, hyperammonemia after fasting & NR & Nakagawa and Guarente 2011 \\
\hline Sir 6 & & Nucleus & $\begin{array}{l}\text { Die around } 4 \text { weeks showing premature aging } \\
\text { phenotype (lymphopenia, loss of subcutaneous fat), } \\
\text { hyperglycemia, increased glucose uptake, genomic } \\
\text { instability }\end{array}$ & $\begin{array}{l}\text { Exhibit growth retardation, with lower } \\
\text { levels of pituitary growth hormone and } \\
\text { IGF-1 }\end{array}$ & $\begin{array}{l}\text { Nakagawa and Guarente 2011; Sebastián et al. } \\
2012\end{array}$ \\
\hline Sir 7 & & Nucleus & $\begin{array}{l}\text { Die around } 1 \text { year showing premature aging } \\
\text { phenotypes (kyphosis, loss of subcutaneous fat, } \\
\text { degenerative cardiac hypertrophy), increased } \\
\text { apoptosis }\end{array}$ & NR & Nakagawa and Guarente 2011 \\
\hline Class IV & $\mathrm{Zn}^{2+}$ & & & & \\
\hline HDAC 11 & & Nucleus & NR & NR & Gao et al. 2002 \\
\hline
\end{tabular}

NR - not reported. 
(HDAC6 and 10) can shuttle between the nucleus and cytoplasm (Khochbin et al., 2001; Wang and Yang 2001; Xu et al., 2007). Of note, only HDAC6 is predominantly cytoplasmic (Guardiola et al., 2002). In some cases class Ila HDACs can also act as transcriptional activators, but in either situation these enzymes primarily control gene expression by recruiting other proteins (corepressors or coactivators) (Martin et al., 2007). The sirtuins, which have an uncommon property in that they require $\mathrm{NAD}^{+}$as a cofactor for their enzymatic activity, are referred to as class III HDACs (Imai et al., 2000; Baur et al., 2012). Class IV HDACs have a unique catalytic domain and are overall structurally distinct from class I and II HDACs (Gregoretti et al., 2004). Class IV currently consists of one member, HDAC 11, with little known of its function. The enzymes belonging to class I, II, III and IV are categorized either "zinc-dependent" or "NAD+-dependent" (sirtuins).

Although histones represent the most intensively studied substrates for these enzymes, at least 50 non-histone proteins of known biological function have been identified, which may be deacetylated by HDACs. These include transcription factors, transcription regulators, signal transduction mediators, DNA repair enzymes, nuclear import regulators, chaperone proteins, structural proteins, inflammation mediators (Xu et al., 2007). Thus, specific modifications of a great number of HDAC substrates indicate the implication of deacetylation in the whole array of biological processes, including among others regulation of development, neurogenesis, apoptosis, synaptogenesis, and neurite outgrowth. Biological functions of individual HDACs have been difficult to define due to the lack of isoform-specific inhibitors. Nevertheless, constitutive deletion of some isoforms of class I HDACs, e.g. HDAC1 or 3 causes severe developmental defects and lethality. Based on these data we can conclude that deacetylases exert prominent influence on physiological processes. It is well known that post-translational modification of histone acetylation states occurs at various developmental stages and any disruption of HDACs function can cause severe defects (Grayson et al., 2005; Veldic et al., 2005) (see Table 1).

\section{Expression of HDAC1 and HDAC2 during brain development}

Neuronal development relies on a number of sequential events where a pool of undifferentiated embryonic progenitor cells give rise to a variety of specialized neurons and glial cells. Several studies revealed redundant and essential roles of both, class I and II HDACs, in multiple levels of development and tissue patterning (De Rubertis et al., 1996; Shi and Mello 1998; Lagger et al. 2002; Brunmeir et al., 2009; Pillai et al., 2004). To support this, some evidence indicate that constitutive deletion of most HDACs lead to severe neuronal death (Haberland et al., 2009a,b). The wide expression pattern of a number of HDACs in the developing brain suggests specific roles for individual HDACs in neuronal development. Studies performed in zebrafish and, more importantly, in small mammals revealed particularly important functions of two deacetylases, HDAC1 and HDAC2, in the central nervous system development (MacDonald and Roskams 2008; Montgomery et al., 2009, Hagelkruys et al., 2014). Both deacetylase isoforms are ubiquitously expressed in a variety of different organisms and according to Dufourcq et al., (2002) can be detected as early as the time of initiation of embryonic transcription. Nevertheless, mRNA and protein levels vary between species and early stages of development (Brunmeir et al., 2009). During the later stage of embryogenesis, expression of both isoforms, HDAC1 and HDAC2, becomes mostly pronounced in the regions displaying ongoing organogenesis. Analysis of several species (e.g. Xenopus, Drosophila melanogaster, zebrafish) revealed noticeable HDAC1 expression in the developing head area, including the central nervous system and brain (Mannervik and Levine 1999; Damjanowski et al., 2000; Mottus et al., 2000; Pillai et al., 2004).

Of note, a significant part of our knowledge about the functions of HDAC1 and HDAC2 in the embryonic nervous system development was provided by extensive studies performed on zebrafish. The study on embryonic brain development of the zebrafish has discovered the existence of a core neurogenic program regulated by histone post-translational modifications (Harrison et al., 2011). Importantly, HDAC1 was identified as a factor regulating positively the transcription of key genes for neuronal specification and patterning during zebrafish development. Moreover, it was found that the mutation of hdac1 caused several developmental defects in this species, such as failure of neuron and glia cell formation in the hindbrain, loss of segmental organization of postmitotic neurons and glia cells, and deficit in branching of motor neurons. The precise mechanism of HDAC-dependent actions are currently not well understood, however it is likely that HDAC1 is involved in the suppression of the Notch-responsive transcriptional repressor resulting in inhibition of proneural gene expression. In addition, HDAC1 has also been implicated in the regulation of developmental signalling cascade such as Hedgehog and Fgf8 during embryonic neurogenesis (Cunliffe 2004; Pillai et al., 2004; Cunliffe and Casaccia-Bonefil 2006).

The in vivo requirement for HDAC1 and HDAC2 in normal embryonic brain development has recently been validated through analysis of mice with double deletion of both isoforms in the brain. This approach resulted in the robust abnormalities of cortical, hippocampal, and cerebellar development. The neuronal defects originated between embryonic day E14.5 and E 16.5, the time of extensive neurogenesis and neuronal migration and can be attributed to a failure of neural precursor differentiation into mature neurons and finally to excessive cell death. The mice did not survive beyond postnatal day 7 . These results indicate that HDAC1 and HDAC2 act as redundant regulators of differentiation during brain structure development. In contrast, deletion of either HDAC1 or HDAC2 individually in the central nervous system does not evoke an overt developmental phenotype in mice, which live to adulthood (Montgomery et al., 2009). In this publication for a selective deletion of HDAC1 or HDAC2, the authors used a Cre/loxP system in cells expressing GFAP (somatic mutation). Despite the common function of both deacetylases, recently published data revealed a major role of HDAC2 in brain development where it controls the fate of neural progenitors, thus contributing to the survival of animals (Hagelkruys et al., 2014).

In addition to the neurodevelopmental abnormalities resulting from the simultaneous loss of HDAC1 and HDAC2, HDAC3 deletion also displays severe neurological deficits and premature death (Norwood et al., 2014).

In all stages of development, HDAC1 is predominantly expressed in proliferating neuro-glial progenitors, but is down-regulated as they differentiate into neurons. On the other hand, this isoform becomes maintained as progenitors differentiate into glia in the postnatal brain. In contrast, expression of HDAC2 is first induced in 
a subset of progenitor cells and is up-regulated as the progenitors commit to a neuronal lineage (Fig.1). Throughout the adult brain HDAC1 expression is primarily glial while HDAC2 is expressed in neurons (McDonald and Roskams 2008; Baltan 2012).

\section{The involvement of HDAC1 and HDAC2 in neurogenesis}

Expression of both deacetylases, HDAC1 and HDAC2, in neural progenitors and stem cells embryonically as well as in adults supports their involvement in the regulation of proliferation and in subsequent phenotypic differentiation - the key steps of neurogenesis (McDonald and Roskams 2008, Humphrey et al., 2008; Montgomery et al., 2009). In addition, deletion of HDAC1 in mouse embryo displays significant reduction in the number of proliferating cells (Lagger et al., 2002). The mechanism of action probably relates, at least in part, to up regulation of the cyclin kinase inhibitor p2 $1^{\mathrm{WAF} 1 / \mathrm{CIP} 1}$ in HDAC1 null cells (Lagger et al., 2002). A Hdac1 mutation in the zebrafish retina, on the other hand, leads to an increase in the number of proliferating cells (Yamaguchi et al., 2005). These obvious discrepancies in the results could be explained by differences in the model employed.

To further evaluate the role of HDACs-mediated effect on cell proliferation several laboratories examined the consequences of deacetylase inhibition. To date, a variety of pharmacological agents (e.g. VPA, NaB, and TSA) were tested in several cell culture systems (including progenitors isolated from neurogenic subgranular and subventricular zones of adult rats, and fetal slice cultures), displaying either a promoting (Hao et al., 2004; Sintoni et al., 2013) or inhibiting (Hsieh et al., 2004; Liu et al., 2012) effect on cell proliferation. Taken together, the obtained results are

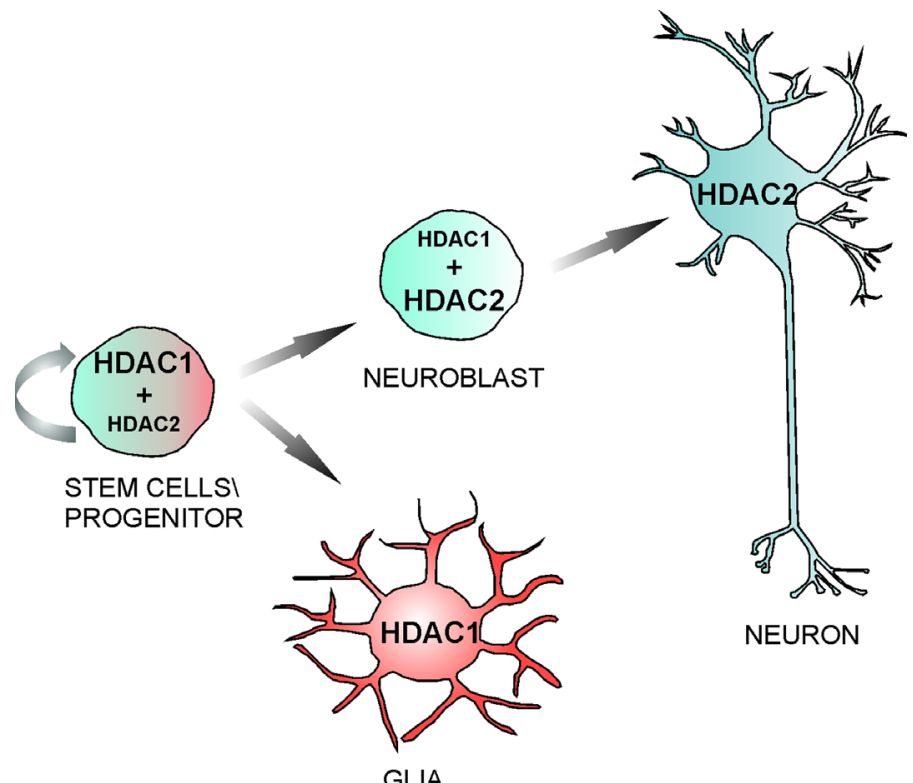

Fig. 1. Expression of HDAC1 and HDAC2 during neural development. HDCA1 is predominantly expressed in proliferating neuro-glial progenitors, but is down-regulated as they differentiate into neurons. Expression of HDAC2 is only weakly detected in some stem/progenitors cells and is upregulated as the progenitors commit to a neuronal lineage. Throughout the adult brain HDAC1 expression is primarily glial while HDAC2 is expressed in neurons. (According to MacDonald and Roskams, 2008, modified). inconclusive. The obtained diverse effect may depend on the origin of precursor cells, as well as the procedures used for neural progenitor isolation.

Importantly, the decreased cell proliferation in the presence of HDAC inhibitors was accompanied by promotion of neuronal phenotypic differentiation (Hsieh et al., 2004; Jessberger et al., 2007; Umka et al., 2010; Yao et al., 2010; Zhou et al., 2011a,b; Huang et al., 2012; Liu et al., 2012) and by simultaneous up-regulation of genes such as NeuroD, SCG19, synapsin, governing differentiation towards neurons (Hao et al., 2004). By contrast, differentiation towards the oligodendrocytes and astrocytes was inhibited.

Neuronal differentiation at the expense of glial differentiation has been noted with a variety of HDAC inhibitors in both embryonic and glial progenitors (Hsieh et al., 2004; Laeng et al., 2004; Siebzehnrubl et al., 2007). This data implicate the necessity of HDAC to repress neuronal genes and then to allow glial differentiation. This hypothesis is consistent with lower levels of acetylated histones in astrocytes and oligodendrocytes in comparison to neurons and neural progenitors. Accordingly, it may be supposed that during differentiation of glial lineages deacetylation is more extensive (Hsieh et al., 2004). In addition, the notable expression of HDAC1 in glial cells during postnatal development may indicate a particular engagement of this isoform in deacetylation during glial development (MacDonald and Roskams, 2008).

In an attempt to delineate the specific function of HDACs "dominant-negative" stem cell lines expressing mutants of HDAC isoforms - HDAC1, HDAC2, and HDAC3, with reduced enzymatic activity but with preserving the ability to form protein complexes, were constructed (Humphrey et al., 2008). It was found that the transduction of fetal stem cells with these mutants shifted cell fate choice to oligodendrocytes. These results indicate that in stem cells HDACs may normally complex with repressors of oligodendrocyte or astrocyte differentiation. Furthermore, the repressor complex may be displaced by glia promoting complexes shortly after mitotic arrest. This suggestion remains in line with the requirement of HDACs activity for maturation of post-mitotic oligodendrocytes (Marin-Husstege et al., 2002). The mentioned above differences in outcomes may reflect the cellular context in which HDAC inhibition occurs.

There is general agreement that histone deacetylases play an essential function in regulating differentiation of neural precursor cells to oligodendrocytes in the developing brain in rodents (MarinHusstege et al., 2002; Shen et al., 2005; Ye et al., 2009; Chen et al., 2011; Jacob et al., 2011). It was reported that genetic ablation of HDAC1 and HDAC2 in the mouse blocks oligodendrocyte differentiation by activation of Wnt/beta catenin signaling pathway. The differentiation process is in part initiated by deacetylation of histone $\mathrm{H} 3$ by HDACs, which leads to down-regulation of myelin inhibitor gene expression and prevents progenitor cells from choosing neuronal or astrocytic lineage commitment (Ye et al., 2009).

In contrast, astrocytic differentiation was not affected by loss of HDAC1 and 2 in progenitor cells. Cells lacking HDAC1 and 2 together were able to differentiate into astrocytes at similar levels as wild-type controls.

The described above finding that treatment with inhibitors of adult or embryonic neuronal precursors specifically induces the differentiation to neurons (Hsieh et al., 2004; Shakèd et al., 2008; Balasubramaniyan et al., 2006) is rather astonishing in light of data showing that deletion of HDAC1and HDAC2 induces cell death 
during differentiation to neurons specifically (Montgomery et al., 2009). A similar phenotype has been noted in a lower organism such as zebrafish where mutants for HDAC1 show a blockade of neuronal differentiation in vivo through the activation of the neurogenic repressor which in consequence leads to significant apoptosis of neural progenitor cells in hindbrain (Cunliffe et al., 2004; Stadler et al., 2005). Moreover, neuronal precursors transduced with a mutant HDAC1 devoid catalytic activity showed a $50 \%$ reduction in neuronal specification (Humphrey et al., 2008). It may be speculated that HDAC proteins remain integrated within transcriptional complexes despite the presence of HDAC inhibitors. In contrast, the complete absence of HDAC proteins may perturb protein-protein integration required for modulation of transcriptional programs that are otherwise insensitive to HDAC inhibition. Thus, taking into account that available inhibitory agents are not highly-specific, studies using conditional knock-out mice presenting complete loss of function provide more insight into the direct role of histone deacetylation in regulating specific aspects of neurogenesis and the potential molecular mechanism.

The present data does not allow us to state if both deacetylase isoforms act independently on one another or cooperate. In fact, HDAC2 is expressed in proliferating progenitors in both the embryo and adult, and is up-regulated in neuroblasts where it could potentially act together with HDAC1 to regulate the cell cycle (Yamaguchi et al., 2005). On the other hand, upon lineage specification into either glial cells or neuroblasts and postmitotic neurons, HDAC1 and 2 present different cellular and subcellular expression and utilize different signaling pathways to influence their substrates. Finally, HDAC2 activity is necessary to inhibit astrocyte differentiation while HDAC1 is not (Humphrey et al., 2008). This may suggest that HDAC2 is involved in silencing glial gene expression, while HDAC1 silences neuronal genes (Humphrey et al., 2008; MacDonald and Roskams 2008). Moreover HDAC1 is not crucial for enzymatic function of HDAC2 in embryonic stem cells, however overexpression of HDAC2 cannot compensate for the loss of HDAC1 (Lagger et al., 2002).

Epigenetic regulation of neurodevelopment contributes to the structural brain tissue pattern during neurogenesis and further continues to impact on cell migration. In accordance with this, alterations in the level of human or $C$. elegans HDAC1 affected cell migration (Whetstine et al., 2005; Zinovyeva et al., 2006), probably by regulating genes involved in the architecture of ECM.

HDACs appear to be also decisive for early synaptogenesis and promotion of synaptic network stability. It is worth pointing out, that the roles of HDACs in control of excitatory synapse maturation and function are covered by Akhtar et al., (2009) and Guan et al., (2009) and will not be addressed in detail. Nevertheless, it is postulated that HDAC1 and HDAC2 form a developmental switch that controls excitatory synapse and function which is dependent on the maturational state of the neurons. During the early synapse development HDAC1 and HDAC2 restrict the progression of excitatory synapse maturation and thereby most probably suppress excitatory neurotransmission. An opposite effect (augmented excitatory neurotransmission) was noted when neuronal networks mature and synapse numbers significantly increase. Interestingly, under the same conditions, HDAC activity does not impact inhibitory neurotransmission, which showed an over 50 fold increase over development, suggesting network specificity in the epigenetic control of synaptic circuits. Together, these results indicate that
HDAC1 and 2 are critical regulators of excitation-inhibition balance in developing synaptic networks through their control of excitatory drive (Akhtar et al., 2009; Jawerka et al., 2010).

\section{Conclusion}

Collectively, the data presented in this mini review highlight the potential significance of HDAC1- and HDAC2-mediated epigenetic regulation of different stages of brain development. It is becoming clear that an extensive number of developmental decisions and differentiation programs depend on HDAC1 and HDAC2 as cofactors. Considering the potential function of HDACs in the nervous system development it should be remembered that histones are not the sole target or substrate of HDAC1 as well as HDAC2. Several HDAC isoforms have been shown to regulate acetylation of a plethora proteins e.g. tubulin, p53, and Hsp90 (Yao et al., 2001; Hubbert et al., 2002; Ito et al., 2002) thus, we cannot rule out the possibility that they might play a more direct role in the nervous system development. Moreover, cell type specific functions still remain to be seen, cross regulatory mechanisms and regulations of deacetylase activity. Future development of this research should be able to increase available data and, in addition, to clarify the role of individual HDACs in different steps of neurodevelopment.

\section{Acknowledgements}

This work was supported by NSC grant no 2012/05/B/NZ3/00436 and POKL.04.03.00-00-060/12. The funders have no role in study design, data collection and analysis, decision to publish, orpreparation of the manuscript.

\section{References}

AKHTAR MW, RAINGO J, NELSON ED, MONTGOMERY RL, OLSON EL, KAVALAL ET, MONTEGGIA LM (2009). Histone deacetylases 1 and 2 form a developmental switch that controls excitatory synapse maturation and function. J Neurosci 29: 8288-8297.

AGIS-BALBOARC, PAVELKAZ, KERIMOGLU C, FISCHERA(2013). Loss of HDAC5 impairs memory function: implications for Alzheimer's disease. J Alzheimers Dis 33: 35-44.

BALASUBRAMANIYAN V, BODDEKE E, BAKELS R, KUST B, KOOISTRAS, VENEMANA, COPRAY S (2006). Effects of histone deacetylation inhibition on neuronal differentiation of embryonic mouse neural stem cells. Neuroscience 143: 939-951.

BALTAN S (2012). Histone deacetylase inhibitors preserve function in aging axons $J$ Neurochem 123 Suppl 2: 108-115.

BARDAI FH, D'MELLO SR (2011). Selective toxicity by HDAC3 in neurons: regulation by Akt and GSK3beta. J Neurosci 31: 1746-1751.

BARDAI FH, PRICE V, ZAAYMAN M, WANG L, D'MELLO SR (2012). Histone deacetylase-1 (HDAC1) is a molecular switch between neuronal survival and death. J Biol Chem 287: 35444-35453.

BAUR JA UNGVARI Z, MINOR RK, LE COUTEUR DG, de CABO R (2012). Are sirtuins viable targets for improving healthspan and lifespan? Nat Rev Drug Discov 11: 443-461.

BRUNMEIR R, LAGGER S, SEISER C (2009). Histone deacetylase HDAC1/HDAC2 controlled embryonic development and cell differentiation. Int J Dev Bio/53:275-289.

CHANG S, YOUNG BD, LI S, QI X, RICHARDSON JA, OLSON EN (2006). Histone deacetylase 7 maintains vascular integrity by repressing matrix metalloproteinase 10. Cell 126: 321-334

CHEN B, CEPKO CL (2009). HDAC4 regulates neuronal survival in normal and diseased retinas. Science 323: 256-259.

CHEN Y, WNAG H, YOON SO, XU X, HOTTIGER MO, SVAREN J, NAVE KA, KIM HA, OLSON EN, LU QR (2011). HDAC-mediated deacetylation of NF-KB is critical for Schwann cell myelination. Nat Neurosci 14: 437-441.

CUNLIFFE VT (2004). Histone deacetylase 1 is required to repress Notch target 
gene expression during zebrafish neurogenesis and to maintain the production of motoneurones in response to hedgehog signalling. Development 131:2983-2995.

CUNLIFFE VT, CASACCIA-BONEFIL P (2006). Histone deacetylase 1 is essential for oligodendrocyte specification in the zebrafish CNS. Mech Dev 123: 24-30.

DAMJANOVSKI S, SACHS LM, SHI YB (2000). Multiple stage-dependent roles for histone deacetylases during amphibian embryogenesis: implications for the involvement of extracellular matrix remodeling. Int J Dev Biol 44: 769-776.

DE RUBERTIS F, KADOSH S, HENCHOZ S, PAULI D, REUTER G, STRUHL K, SPIERERP (1996). The histone deacetylase RPD3 counteracts genomic silencing in Drosophila and yeast. Nature 384: 589-591.

DOMPIERRE JP, GODIN JD, CHARRIN BC, CORDELIERES FP, KING SJ, HUMBERT S, SAUDOU F (2007). Histone deacetylase 6 inhibition compensates for the transport deficit in Huntington's disease by increasing tubulin acetylation. $J$ Neurosci 27: 3571-3583.

DUFOURCQ P, VICTOR M, GAY F, CALVO D, HODGKIN J, SHIY (2002). Functional requirement for histone deacetylase 1 in Caenorhabditis elegans gonadogenesis. Mol Cell Biol 22: 3024-3034.

EGGER G, LIANG G, APARICIO A, JONES PA (2004). Epigenetics in human disease and prospects for epigenetic therapy. Nature 429: 457-463.

FINKEL T, DENG CX, MOSTOSLAVSKY R (2009). Recent progress in the biology and physiology of sirtuins. Nature 460: 587-591

FUKADA M, HANAI A, NAKAYAMA A, SUZUKI T, MIYATA N, RODRIGUIZ RM, WETSEL WC, YAO TP, KAWAGUCHI Y (2012). Loss of deacetylation activity of Hdac6 affects emotional behavior in mice. PLoS One 7: e30924.

GAO L, CUETO MA, ASSELBERGS F, ATADJA P (2002). Cloning and functional characterization of HDAC11, a novel member of the human histone deacetylase family. J Biol Chem 277: 25748-25755.

GRAYSON DR, JIA X, CHEN Y, SHARMA RP, MITCHELL CP, GUIDOTTI A, COSTA E (2005). Reelin promoter hypermethylation in schizophrenia. Proc Natl Acad Sci USA 102: 9341-9346.

GREGORETTI IV, LEE YM, GOODSON HV (2004). Molecular evolution of the histone deacetylase family: functional implications of phylogenetic analysis. $J$ Mol Biol 338: 17-31.

GUAN JS, HAGGARTY SJ, GIACOMETTI E, DANNENBERG JH, JOSEPH N, GAO J, NIELAND TJ, ZHOU Y, WANG X, MAZITSCHEK R, BRADNER JE, DePINHO RA, JAENISCH R, TSAI LH (2009). HDAC2 negatively regulates memory formation and synaptic plasticity. Nature 459: 55-60.

GUARDIOLAAR, YAO TP (2002). Molecular cloning and characterization of a novel histone deacetylase HDAC10. J Biol Chem 277: 3350-3356.

HABERLAND M, MONTGOMERY RL, OLSON EN (2009a). The many roles of histone deacetylases in development and physiology: implications for disease and therapy. Nat Rev Genet 10: 32-42.

HABERLAND M, MOKALLED MH, MONTGOMERY RL, OLSON EL (2009b). Epigenetic control of skull morphogenesis by histone deacetylase 8. Genes Dev 23: 1625-1630.

HAGELKRUYSA, LAGGER S, KRAHMER J, LEOPOLDIA, ARTAKER M, PUSCHO, ZEZULA J, WEISSMANN S, XIE Y, SCHOFER C, SCHLEDERER M, BROSCH G, MATTHIAS P, SELFRIDGE J, LASSMANN H, KNOBLICH JA, SEISER C (2014). A single allele of Hdac2 but not Hdac1 is sufficient for normal mouse brain development in the absence of its paralog. Development 141: 604-616.

HAO Y, CRESON T, ZHANG L, LI P, DU F, YUAN P, GOULD TD, MANJI HK, CHEN G (2004). Mood stabilizer valproate promotes ERK pathway-dependent cortical neuronal growth and neurogenesis. J Neurosci 24: 6590-6599.

HARRISON MR, GEORGIOU AS, SPAINK HP, CUNLIFFE VT (2011). The epigenetic regulator Histone Deacetylase 1 promotes transcription of a core neurogenic programme in zebrafish embryos. BMC Genomics 12: 24.

HSIEH J, NAKASHIMA K, KUWABARA T, MEJIA E, GAGE FH (2004). Histone deacetylase inhibition-mediated neuronal differentiation of multipotent adult neural progenitor cells. Proc Natl Acad Sci USA 101: 16659-16664.

HUANG HY, LIU DD, CHANG HF, CHEN WF, HSU HR, KUO JS, WANG MJ (2012). Histone deacetylase inhibition mediates urocortin-induced antiproliferation and neuronal differentiation in neural stem cells. Stem Cells 30: 2760-2773.

HUBBERT C, GUARDIOLAA, SHAO R, KAWAGUCHI Y, ITO A, NIXON A, YOSHIDA $M$, WANG XF, YAO TP (2002). HDAC6 is a microtubule-associated deacetylase. Nature 417: 455-458.
HUMPHREY GW, WANG YH, HIRAI T, PADMANABHAN R, PANCHSION DM, NEWELL LF, McKAY RD, HOWARD BH (2008). Complementary roles for histone deacetylases 1, 2, and 3 in differentiation of pluripotent stem cells. Differentiation 76: 348-356.

IMAI S, ARMSTRONG CM, KAEBERLEIN M, GUARENTE L (2000). Transcriptional silencing and longevity protein Sir2 is an NAD-dependent histone deacetylase. Nature 403: 795-800.

ITO A, KAWAGUCHI Y, LAI CH, KOVACS JJ, HIGASHIMOTO Y, APPELLA E, YAO TP (2002). MDM2-HDAC1-mediated deacetylation of p53 is required for its degradation. EMBO $J 21$ : 6236-6245.

JACOB C, LEBRUN-JULIEN F, SUTER U (2011). How histone deacetylases control myelination. Mol Neurobiol 44: 303-312.

JAWERKA M, COLAK D, DIMOU L, SPILLER C, LAGGER S, MONTGOMERY RL, OLSON EN, WURST W, GOTTLICHER M, GOTZ M (2010). The specific role of histone deacetylase 2 in adult neurogenesis. Neuron Glia Biol 6: 93-107.

JESSBERGERS, NAKASHIMAK, CLEMENSON GD Jr, MEJIAE, MATHEWSE, URE K, OGAWAS, SINTON CM, GAGE FH, HSIEH J (2007). Epigenetic modulation of seizure-induced neurogenesis and cognitive decline. J Neurosci 27: 5967-5975.

KAO HY, LEE CH, KOMAROV A, HAN CC, EVANS RM (2002). Isolation and characterization of mammalian HDAC10, a novel histone deacetylase. J Biol Chem 277: 187-193.

KHOCHBINS, VERDELA, LEMERCIERC, SEIGNEURIN-BERNYD(2001). Functional significance of histone deacetylase diversity. Curr Opin Genet Dev 11: 162-166.

KIM D, FRANK CL, DOBBIN MM, TSUNEMOTO RK, TU W, PENG PL, GUAN JS, LEE BH, MOY LY, GIUSTI P, BROODIE N, MAZITSCHEK R, DELALLE I, HAGGARTY SJ, NEVE RL, LU Y, TSAI LH (2008). Deregulation of HDAC1 by p25/ Cdk5 in neurotoxicity. Neuron 60: 803-817.

KIM HJ, BAE SC (2011). Histone deacetylase inhibitors: molecular mechanisms of action and clinical trials as anti-cancer drugs. Am J Transl Res 3: 166-179.

KIM MS, AKHTAR MW, ADACHI M, MAHGOUB M, BASSEL-DUBY R, KAVALALI ET, OLSON EN, MONTEGGIA LM (2012). An essential role for histone deacetylase 4 in synaptic plasticity and memory formation. J Neurosci 32: 10879-10886.

LAENG P, PITTS RL, LEMIREAL, DRABIKCE, WEINERA, TANG H, THYAGARAJAN R, MALLON BS, ALTAR CA (2004). The mood stabilizer valproic acid stimulates GABA neurogenesis from rat forebrain stem cells. J Neurochem 91: 238-251.

LAGGER G, O'CARROLL D, REMBOLD M, KHIER H, TISCHLER J, WEITZER G, SCHUETTENGRUBER B, HAUSER C, BRUNMEIR R, JENUWEIN T, SEISER $C$ (2002). Essential function of histone deacetylase 1 in proliferation control and CDK inhibitor repression. EMBO J 21: 2672-2681.

LINSEMAN DA, BARTLEY CM, LE SS, LAESSIG TA, BOUCHARD RJ, MEINTZER MK, LI M, HEIDENREICHKA(2003). Inactivation of the myocyte enhancer factor-2 repressor histone deacetylase- 5 by endogenous $\mathrm{Ca}(2+) / /$ calmodulin-dependent kinase II promotes depolarization-mediated cerebellar granule neuron survival. J Biol Chem 278: 41472-41481.

LIU H, WU H, WANG Y, WANG Y, WU X, JU S, WANG X (2012). Inhibition of class II histone deacetylase blocks proliferation and promotes neuronal differentiation of the embryonic rat neural progenitor cells. Acta Neurobiol Exp (Wars) 72: 365-376.

MAC, D'MELLOSR (2011). Neuroprotection by histone deacetylase-7 (HDAC7) occurs by inhibition of c-jun expression through a deacetylase-independent mechanism. J Biol Chem 286: 4819-2488.

MACDONALD JL, ROSKAMSAJ (2008). Histone deacetylases 1 and 2 are expressed at distinct stages of neuro-glial development. Dev Dyn 237: 2256-2267.

MAJDZADEHN, WANG L, MORRISONBE, BASSEL-DUBYR, OLSONEN, D'MELLO SR (2008). HDAC4 inhibits cell-cycle progression and protects neurons from cell death. Dev Neurobiol 68: 1076-1092.

MANNERVIK M, LEVINE M (1999). The Rpd3 histone deacetylase is required for segmentation of the Drosophila embryo. Proc Natl Acad Sci USA 96: 6797-6801.

MARIN-HUSSTEGE M, MUGGIRONI M, LIU A, CASACCIA-BONNEFIL P (2002). Histone deacetylase activity is necessary for oligodendrocyte lineage progression. J Neurosci 22: 10333-10345.

MARKS PA, MILLER T, RICHON VM (2003). Histone deacetylases. Curr Opin Pharmacol 3: 344-351.

MARTIN M, KETTMANN R, DEQUIEDT F (2007). Class lla histone deacetylases: regulating the regulators. Oncogene. 26: 5450-5467.

MCQUOWN SC, BARRETT RM, MATHEOS DP, POST RJ, ROGGE GA, ALENG- 
HAT T, MULLICAN SE, JONES S, RUSCHE JR, LAZAR MA, WOOD MA (2011). HDAC3 is a critical negative regulator of long-term memory formation. $J$ NeurosCi 31: 764-774.

MONTGOMERY RL, DAVIS CA, POTTHOFF MJ, HABERLAND M, FIELITZJ, QI X, HILL JA, RICHARDSON JA, OLSON EN (2007). Histone deacetylases 1 and 2 redundantly reg-ulate cardiac morphogenesis, growth, and contractility. Genes Dev 21: 1790-1802.

MONTGOMERY RL, POTTHOFF MJ, HABERLAND M, QI X, MATSUZAKI S, HUMPHRIES KM, RICHARDSON JA, BASSEL-DUBY R, OLSON EN (2008). Maintenance of cardiac energy metabolism by histone deacetylase 3 in mice. $J$ Clin Invest 118: 3588-3597.

MONTGOMERY RL, HSIEH J, BARBOSA AC, RICHARDSON JA, OLSON EN (2009). Histone deacetylases 1 and 2 control the progression of neural precursors to neurons during brain development. Proc Natl Acad Sci USA 106: 7876-7881

MORRIS MJ, MAHGOUB M, NA ES, PRANAV H, MONTEGGIA LM (2013). LosS of histone deacetylase 2 improves working memory and accelerates extinction learning. J Neurosci 33: 6401-6411.

MORRISON BE, MAJDZADEH N, ZHANG X, LYLES A, BASSEL-DUBY R, OLSON EN, D'MELLOSR (2006). Neuroprotection by histone deacetylase-related protein. Mol Cell Biol 26: 3550-3564.

MOTTUS R, SOBEL RE, GRIGLIATTI TA (2000). Mutational analysis of a histone deacetylase in Drosophila melanogaster. missense mutations suppress gene silencing associated with position effect variegation. Genetics 154: 657-668.

NAKAGAWAT, GUARENTE L (2011). Sirtuins at a glance. J Cell Sci124(Pt6): 833-838.

NORWOOD J, FRANKLIN JM, SHARMAD, D'MELLOSR (2014). Histone deacetylase 3 is necessary for proper brain development. J Biol Chem 289: 34569-34582.

PANDEY UB, BATLEVI Y, BAEHRECKE EH, TAYLOR JP (2007a). HDAC6 at the intersection of autophagy, the ubiquitin-proteasome system and neurodegeneration. Autophagy 3: 643-645.

PANDEY UB, NIE Z, BATLEVI Y, MCCRAY BA, RITSON GP, NEDELSKY NB, SCHWARTZSL, DiPROSPERONA, KNIGHTMA, SCHULDINERO, PADMANABHAN R, HILD M, BERRY DL, GARZA D, HUBBERT CC, YAO TP, BAEHRECKE EH, TAYLOR JP (2007b). HDAC6 rescues neurodegeneration and provides an essential link between autophagy and the UPS. Nature 447: 859-863.

PILLAI R, COVERDALE LE, DUBEY G, MARTIN CC (2004). Histone deacetylase 1 (HDAC-1) required for the normal formation of craniofacial cartilage and pectoral fins of the zebrafish. Dev Dyn 231: 647-654.

RENTHAL W, MAZE I, KRISHNAN V, COVINGTON HE $3^{\text {rd }}$, XIAO G, KUMAR A, RUSSO SJ, GRAHAM A, TSANKOVA N, KIPPIN TE, KERSTETTER KA, NEVE RL, HAGGARTY SJ, McKINSEY TA, BASSEL-DUBY R, OLSON EN, NESTLER EJ (2007). Histone deacetylase 5 epigenetically controls behavioral adaptations to chronic emotional stimuli. Neuron 56: 517-529.

RIVIECCIO MA, BROCHIER C, WILLIS DE, WALKER BA, D'ANNIBALE MA, MCLAUGHLIN K, SIDDIG A, KOZIKOWSKI AP, JAFFREY SR, TWISS JL, RATAN RR, LANGLEY B (2009). HDAC6 is a target for protection and regeneration following injury in the nervous system. Proc Natl Acad Sci USA 106: 19599-19604.

SAHA RN, PAHAN K (2006). HATs and HDACs in neurodegeneration: a tale of disconcerted acetylation homeostasis. Cell Death Differ 13: 539-550.

SANDO R $3^{\text {rd }}$, GOUNKO N, PIERAUT S, LIAO L, YATES J $3^{\text {rd }}$, MAXIMOV A (2012). HDAC4 governs a transcriptional program essential for synaptic plasticity and memory. Cell 151: 821-834.

SEBASTIÁN C, ZWAANS BM, SILBERMAN DM, GYMREK M, GORENA, ZHONG L, RAM O, TRUELOVE J, GUIMARAES AR, TOIBER D, COSENTINO C, GREENSON JK, MacDONALD AI, MCGLYNN L, MAXWELL F, EDWARDS J, GIACOSA S, GUCCIONE E, WEISSLEDER R, BERNSTEIN BE, REGEV A, SHIELS PG, LOMBARD DB, MOSTOSLAVSKY R (2012). The histone deacetylase SIRT6 is a tumor suppressor that controls cancer metabolism. Cell 151: 1185-1199.

SHAKĖD M, WEISSMULLER K, SVOBODA H, HORTSCHANSKY P, NISHINO N, WOLFL S, TUCKER KL (2008). Histone deacetylases control neurogenesis in embryonic brain by inhibition of BMP2/4 signaling. PLoS One 3: e2668.

SHEN S, LI J, CASACCIA-BONNEFIL P (2005). Histone modifications affect timing of oligodendrocyte progenitor differentiation in the developing rat brain. $J$ Cell Biol 169: 577-589.

SHI Y, MELLO C (1998). A CBP/p300 homolog specifies multiple differentiation pathways in Caenorhabditis elegans. Genes Dev 12: 943-955

SIEBZEHNRUBLFA, BUSLEI R, EYUPOGLUIY, SEUFERTS, HAHNENE, BLUMCKE I (2007). Histone deacetylase inhibitors increase neuronal differentiation in adult forebrain precursor cells. Exp Brain Res 176: 672-678.

SINTONI S, KURTYS E, SCANDAGLIA M, CONTESTABILE A, MONTI B (2013). Chronic valproic acid administration impairs contextual memory and dysregulates hippocampal GSK-3 $\beta$ in rats. Pharmacol Biochem Behav 106: 8-15.

STADLER JA, SHKUMATAVAA, NORTON WH, RAU MJ, GEISLER R, FISCHER S, NEUMANN CJ (2005). Histone deacetylase 1 is required for cell cycle exit and differentiation in the zebrafish retina. Dev Dyn 233: 883-889.

STRAHL BD, ALLIS CD (2000). The language of covalent histone modifications. Nature 403: 41-45.

THIAGALINGAM S, CHENG KH, LEE HJ, MINEVA N, THIAGALINGAM A, PONTE JF (2003). Histone deacetylases: unique players in shaping the epigenetic histone code. Ann N Y Acad Sci 983: 84-100.

UMKAJ, MUSTAFAS, EIBELTAGY M, THORPEA, LATIF L, BENNETT G, WIGMORE PM (2010). Valproic acid reduces spatial working memory and cell proliferation in the hippocampus. Neuroscience 166: 15-22.

VEGA RB, MATSUDA K, OH J, BARBOSA AC, YANG X, MEADOWS E, MCANALLY J, POMAJZL C, SHELTON JM, RICHARDSON JA, KARSENTY G, OLSON EN (2004). Histone deacetylase 4 controls chondrocyte hypertrophy during skeletogenesis. Cell 119: 555-566.

VELDIC M, GUIDOTTI A, MALOKU E, DAVIS JM, COSTA E (2005). In psychosis, cortical interneurons overexpress DNA-methyltransferase 1. Proc Natl Acad Sci USA 102: 2152-2157.

VERDINE, DEQUIEDTF, KASLERHG (2003). Class II histone deacetylases: versatile regulators. Trends Genet 19: 286-293.

WANG AH, YANG XJ (2001). Histone deacetylase 4 possesses intrinsic nuclear import and export signals. Mol Cell Biol 21: 5992-6005.

WHETSTINE JR, CERON J, LADD B, DUFOURCQ P, REINKE V, SHI Y (2005) Regulation of tissue-specific and extracellular matrix-related genes by a class $I$ histone deacetylase. Mol Cell 18: 483-490.

WILSONAJ, BYUNDS, POPOVAN, MURRAYLB, L'ITALIENK, SOWAY, ARANGOD, VELCICHA, AUGENLICHT LH, MARIADASON JM (2006). Histone deacetylase 3 (HDAC3) and other class I HDACs regulate colon cell maturation and p21 expression and are deregulated in human colon cancer. J Biol Chem 281: 13548-13558.

XU WS, PARMIGIANI RB, MARKS PA (2007). Histone deacetylase inhibitors: molecular mechanisms of action. Oncogene 26: 5541-5552.

YAMAGUCHI M, TONOU-FUJIMORI N, KOMORIA, MAEDAR, NOJIMAY, LIH, OKAMOTO H, MASAI I (2005). Histone deacetylase 1 regulates retinal neurogenesis in zebrafish by suppressing Wnt and Notch signaling pathways. Development 132: 3027-3043.

YAOX, ZHANG JR, HUANG HR, DAI LC, LIU QJ, ZHANG M (2010). Histone deacetylase inhibitor promotes differentiation of embryonic stem cells into neural cells in adherent monoculture. Chin Med J (Engl) 123: 734-738.

YAO YL, YANG WM, SETO E (2001). Regulation of transcription factor YY1 by acetylation and deacetylation. $\mathrm{Mol} \mathrm{Cell}$ Biol 21: 5979-5991.

YE F, CHEN Y, HOANG T, MONTGOMERY RL, ZHAO XH, BU H, HU T, TAKETO MM, van ES JH, CLEVERS H, HSIEH J, BASSEL-DUBY R, OLSON EN, LU QR (2009). HDAC1 and HDAC2 regulate oligodendrocyte differentiation by disrupting the beta-catenin-TCF interaction. Nat Neurosci 12: 829-838.

ZHANG Y, NG HH, ERDJUMENT-BROMAGE H, TEMPST P, BIRD A, REINBERG $D$ (1999). Analysis of the NuRD subunits reveals a histone deacetylase core complex and a connection with DNA methylation. Genes Dev 13: 1924-1935.

ZHOU Q, DALGARD CL, WYNDER C, DOUGHTY ML (2011a). Histone deacetylase inhibitors SAHA and sodium butyrate block G1-to-S cell cycle progression in neurosphere formation by adult subventricular cells. BMC Neurosci 12: 50 .

ZHOU Q, DALGARD CL, WYNDER C, DOUGHTY ML (2011b). Valproic acid inhibits neurosphere formation by adult subventricular cells by a lithium-sensitive mechanism. Neurosci Lett 500: 202-206.

ZINOVYEVAAY, GRAHAM SM, CLOUD VJ, FORRESTERWC (2006). The C. elegans histone deacetylase HDA-1 is required for cell migration and axon pathfinding. Dev Biol 289: 229-242. 


\section{Further Related Reading, published previously in the Int. J. Dev. Biol.}

Opposing actions of histone deacetylase 1 and Notch signalling restrict expression of erm and fgf20a to hindbrain rhombomere centres during zebrafish neurogenesis

Elewys G. Lightman, Michael R.M. Harrison and Vincent T. Cunliffe

Int. J. Dev. Biol. (2011) 55: 597-602

http://dx.doi.org/10.1387/ijdb.113315el

Expression of class I histone deacetylases during chick and mouse development

Christina Murko, Sabine Lagger, Marianne Steiner, Christian Seiser, Christian Schoefer and Oliver Pusch

Int. J. Dev. Biol. (2010) 54: 1527-1537

http://dx.doi.org/10.1387/ijdb.092971cm

Interplay between DNA methylation, histone modification and chromatin remodeling in stem cells and during development

Kohta Ikegami, Jun Ohgane, Satoshi Tanaka, Shintaro Yagi, and Kunio Shiota

Int. J. Dev. Biol. (2009) 53: 203-214

http://dx.doi.org/10.1387/ijdb.082741ki

Class Ila histone deacetylases: conducting development and differentiation Maud Martin, Richard Kettmann and Franck Dequiedt

Int. J. Dev. Biol. (2009) 53: 291-301

http://dx.doi.org/10.1387/ijdb.082698mm

Histone deacetylase 1 and 2-controlled embryonic development and cell differentiation Reinhard Brunmeir, Sabine Lagger and Christian Seiser

Int. J. Dev. Biol. (2009) 53: 275-289

http://dx.doi.org/10.1387/ijdb.082649rb

5 yr ISI Impact Factor $(2013)=2.879$
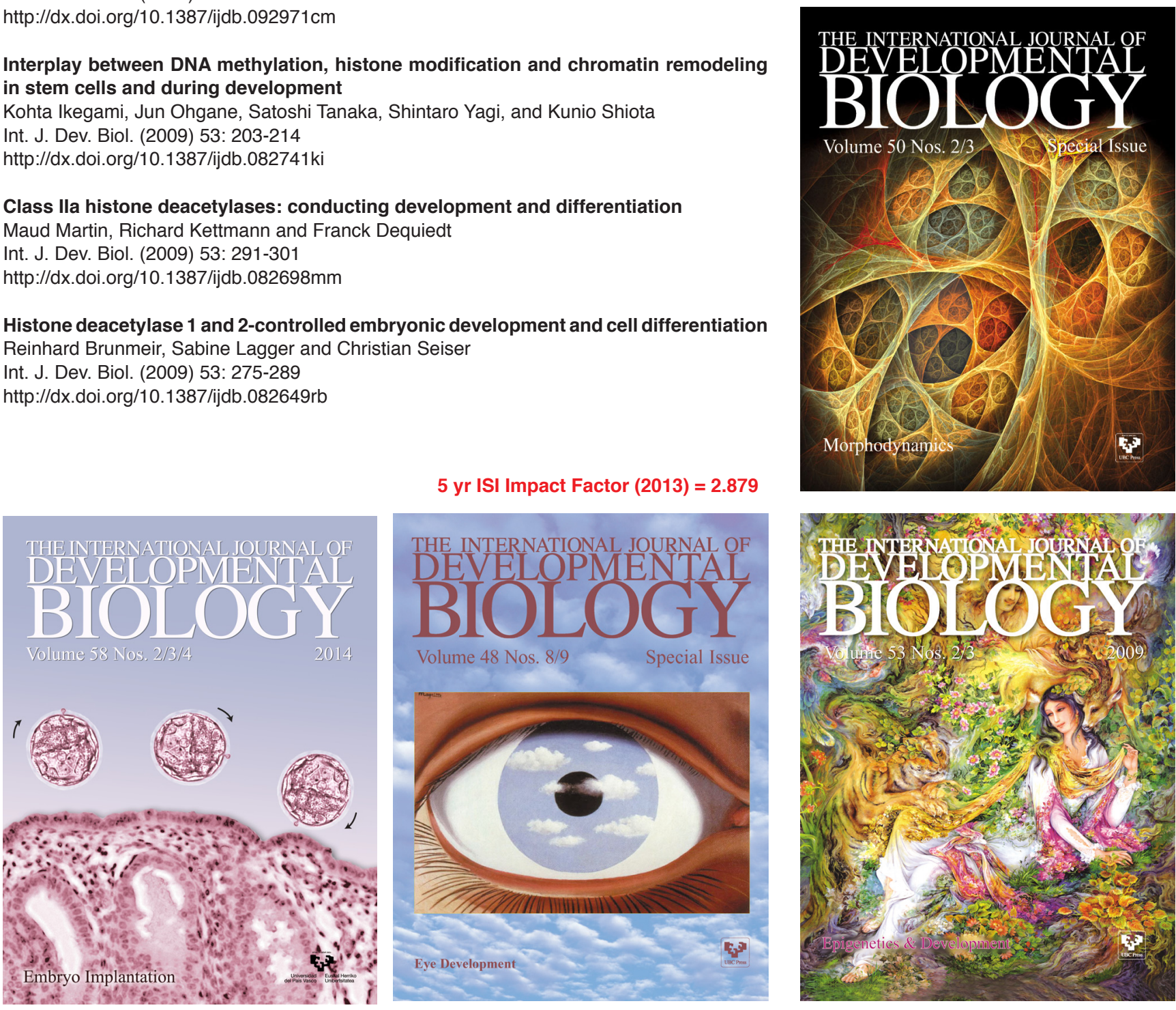